\title{
THE VIABILITY OF Lactobacillus plantarum FROM INTESTINES OF LAYING DUCKS ENCAPSULATED WITH ARABIC GUM AND SKIMMED MILK
}

\author{
Badat Muwakhid $^{1)}$, Anik Maunatin ${ }^{2)}$, Anif Mukaromah Wati ${ }^{3)}$ \\ 1) Faculty of Animal Husbandry University of Islam Malang, Jl.Mayjen Haryono 193 Malang, \\ 65144 East Java, Indonesia \\ ${ }^{2)}$ Department of Chemistry, Maulana Malik Ibrahim State Islamic University Malang, Jl. Gajayana 50, Malang, \\ 65145 East Java, Indonesia \\ 3) Faculty of Animal Science University of Brawijaya. Jl. Veteran Malang, 65145 East Java, Indonesia \\ *Corresponding Email: badatmuwakhid@unisma.ac.id
}

Submitted 16 April 2021 ; Accepted 4 October 2021

\begin{abstract}
The aim of this study was to evaluate the effect of the types of encapsulation materials, that is skimmed milk and Arabic gum on two probiotics Lactic Acid Bacteria (LAB), including L. plantarum DJ2 and L. plantarum DJ3. The methods of this study were separated into two stages that is probiotic resistance testing during the spray drying process and the viability of $\mathrm{LAB}$ after spray drying during storage of probiotic powder for one month at $4^{\circ} \mathrm{C}$. Changes in the viability of $\mathrm{LAB}$ probiotics before and after the drying process using spray drying were determined by the total plate count. The viability of lactic acid bacteria (LAB) was observed every week for one month of storage at $4^{\circ} \mathrm{C}$. The results showed that different encapsulation materials had significant different $(\mathrm{P} \leq 0.05)$ on changes in resistance of probiotics powder during spray drying process. The use of Arabic gum could increase the resistance of probiotics during the spray drying process, meanwhile, the use of skimmed milk was better to be able to maintain the viability of dry probiotic powder both on L.plantarum DJ2 and L.plantarum DJ3 during storage. After four weeks of storage, there was mold and yeast in the skimmed milk and Arabic gum materials. In conclusion, both Arabic gum and skim milk could be used for encapsulation where storage of dry probiotic products is recommended during one month at $4^{\circ} \mathrm{C}$.
\end{abstract}

Key words: Arabic gum; encapsulation; skimmed milk 


\section{INTRODUCTION}

The community's need for animal protein has increased along with the increase in population. In September 2019 each Indonesian population consumed $62.43 \mathrm{~g}$ protein per capita per day. The protein consumption of the Indonesian population was already above the National Consumption Standard of Sufficiency (BPSStatistics Indonesia, 2020). In this regard, the productivity of livestock especially poultry needs to be increased to meet the community's need for animal protein. Probiotics have been widely needed to increase the production efficiency of laying ducks: to enhance immunity, replace the role of antibiotics in feed and increase feed digestibility. Provision of probiotics (feed additives) can be added to animal feed to improve livestock health, reduce mortality, increase feed conversion efficiency and can increase livestock growth and productivity (Yirga, 2015). Markowiak and Śliżewska (2018) stated that provision of probiotics into feed can increase livestock production, including increasing egg, meat, milk production as well as improving feed quality and feed absorption. So far, most of the source of feed for laying ducks, which are cheap and easy to get, have high crude fiber content.

Poultry is still needed crude fiber to support growth but the amount has a low ability. Duck's caecum can digest crude fiber because of the presense of microorganisms in caecum. The function of intestinal microbes is as a digestive system and a provider of nutrients from food that has not been fully utilized by the body (Deng Pan and Zhongtang $\mathrm{Yu}, 2014)$. It is necessary to use probiotic LAB which has cellulolytic ability in ducks feed. Probiotics use prevention and treatment for some diseases with the specific immune and physiological effects in health and disease. In order the viability of probiotic bacteria to remain good, it is necessary to protect bacteria, one of which is the encapsulation method.

The use of materials for encapsulation needed to be considered, because each material has different characters and did not necessarily match the core material to be encapsulated (Rodrigues et al., 2020). To extend the shelf life of bioactive components, encapsulation techniques can be used. In order for the encapsulation to be effective, it is necessary to select an encapsulation material based on carbohydrates, proteins and lipids (Khanvilkar et al., 2016).

Encapsulation has been widely used to increase stability, protect bioactive compounds, decrease biological risk, and enhance aroma and taste. In order to be applied in the industrial sector, probiotics must have the ability to survive the preservation and storage processes. Encapsulation is used to increase the viability of lactic acid bacteria (Afrizal et al., 2019). Encapsulation for probiotics serves to protect the survival of probiotics during the shelf life (environment) and during the intestine (Chavarri et al., 2012). Some of the benefits of encapsulation include being widely used to maintain product nutrition and bioactive components (Samedi and Charles, 2019). Oberoi et al. (2019) stated that for sensitive components such as microorganisms, they could be encapsulated to increase their viability and shelf life. Other previous researches from Ozdal et al. (2020) stated that the methods used for encapsulation had been developed such as nanoemulsions, electrospinning,

How to cite:

Muwakhid, B., Maunantin, A., \& Wati, A. M. (2021). The Viability of Lactobacillus plantarum From Intestines of Laying Ducks Encapsulated with Arabic Gum and Skimmed Milk. Jurnal Ilmu dan Teknologi Hasil Ternak (JITEK), 16 (3), 190-199 
PEGylation, extrusion, coacervation and spray drying. Materials commonly used for encapsulation are various types of polysaccharides and proteins such as starch, alginates, Arabic gum, gelatin, carrageenan, albumin and casein. Arabic gum is defined as a non-functional hydrocolloid natural branch chain with the arabino-galactant protein complex, which has slightly acidic and very neutral properties.

Chewing gum contains magnesium, calcium, and potassium where the use of Arabic gum is for pharmaceutical, food, and others (Musa et al., 2018). Arabic gum is classified as indigestible and is therefore suitable as a prebiotic. Another study states that Arabic gum can treat kidney sufferers, and diarrhea in adults and children (Omer and Hilali, 2016). The other hand, The microparticles contained in milk significantly increased the viability of $L$. acidophilus La-5 (Maciel et al., 2014). For skimmed milk, the advantages of cheese made from skim milk are that it is tougher, has better organoleptic properties and can be used as an alternative for people looking for low-fat milk (Czy'zak-Runowska et al., 2020). To produce a product that is ready to be marketed and consumed directly by ducks, this research will make dry probiotic products from two types of lactic acid bacteria that have cellulolytic capabilities which are the result. In this study, L.plantarum DJ2 and L.plantarum DJ3 were obtained from the intestines of laying ducks. The purpose of this study was to determine the effect of the types of encapsulation materials, including skimmed milk and Arabic gum on LAB L.plantarum DJ2 and L.plantarum on probiotic resistance after spray drying and their viability after storage for one month at $4^{\circ} \mathrm{C}$.

\section{MATERIALS AND METHODS}

This research was conducted at FSaintek UIN Malik Ibrahim Malang in March-December 2019. The materials used include MRS agar (deMan-Rogosa-Sharpe Agar) and MRS broth (deMan-RogosaSharpe Broth) (Merck), Lactic Acid Bacteria that used were Lactobacillus plantarum DJ2 and Lactobacillus plantarum DJ3 isolated from the small intestine of Mojosari laying ducks (Anas plathyrinchos). In this study, before using Lactic Acid Bacteria (LAB) isolates from Mojosari ducks, these isolates need to be reconfirmed with Gram staining and catalase test.

The LAB isolates selected were Lactobacillus plantarum DJ2 and Lactobacillus plantarum DJ3. The results showed that L.plantarum DJ2 and L.plantarum DJ3 had rod shape, Gram positive and catalase negative. The results of Gram staining of L.plantarum DJ2 and L.plantarum DJ3 can be seen in Figure 1 and Figure 1.

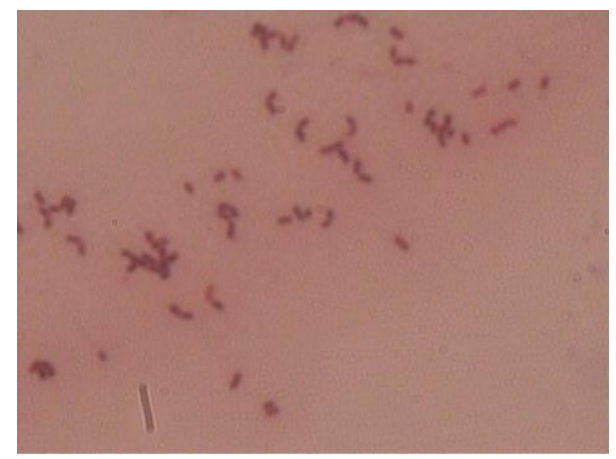

(a)

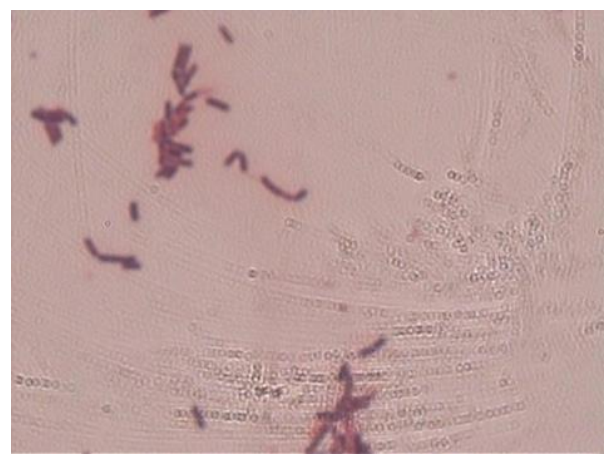

(b)

Figure 1. Gram staining: ( a) L.plantarum DJ2 (b) L.plantarum DJ3

This study does not have ethical clearance because it does not use experimental animals. This study used with two treatments and four replications. The treatments in this study were the use of encapsulation materials, namely skimmed 
milk and Arabic gum (food grade spesification) on $L$. plantarum $\mathrm{DJ} 2$ and $L$. plantarum DJ3 for the manufacture of dry probiotic products. The research work procedures consisted of 1) production of inoculum and LAB biomass, 2) encapsulation of LAB and drying by spray drying, 3) resistance of $\mathrm{LAB}$ during the spray drying process and 4) Changes in the viability of LAB from spray drying during storage.

\section{Encapsulation of BAL Probiotic and Spray Drying}

The use of different encapsulation materials was used to determine the best encapsulation materials L.plantarum DJ2 and L.plantarum DJ3 to produce probiotics with viability that met the requirements. The encapsulation materials used in this study were skimmed milk and Arabic gum, with a ratio of biomass and encapsulation materials 3:7 (w/w). Several microencapsulation studies reported that the average use of encapsulation materials that functioned as encapsulants were at least $60 \%$, which was generally used as much as $80-75 \%$ of encapsulation materials (Kavitake et al., 2018). Encapsulation using a Buchi mini spray dryer B-290, modified method from Sosnik and Seremeta (2015), using a temperature of $150^{\circ} \mathrm{C}$. The parameters observed in the encapsulation results using two types of encapsulation materials were probiotic resistance during the spray drying process, changes in the viability of dry LAB during storage and total contaminants (molds and yeasts) of dry LAB products during storage. The storage of probiotics flour products in this study was carried out at $4^{\circ} \mathrm{C}$.

\section{Research Procedure \\ Preparation of inoculum and LAB biomass}

Probiotics LAB culture was made by taking 2 ose cultures of L.plantarum DJ2 and L.plantarum DJ3 from agar slants that has been fermented for $48 \mathrm{~h}$ and grown on $100 \mathrm{ml}$ MRS broth medium and incubated for $18-20 \mathrm{~h}$ at room temperature. The timing is based on the exponential stage. The inoculum used was measured for its turbidity based on optical density (OD) 0.5 at a wavelength of $600 \mathrm{~nm}$. Furthermore, $30 \mathrm{ml}$ of inoculum was taken to be grown on $300 \mathrm{ml}$ MRS broth and incubated for $18 \mathrm{~h}$ at room temperature. Harvesting time is was optimum time for incubation of $L$. plantarum DJ2 and L. plantarum DJ3 based on preliminary research. Bacterial cell was obtained by centrifugation at 5000xg for $15 \mathrm{~min}$ at $4^{\circ} \mathrm{C}$, then the filtrate was removed (Fossi and Ndjouenkeu, 2017).

\section{Encapsulation of LAB and Spray Drying process}

Probiotics LAB culture used before encapsulation is in the form of biomass. The obtained biomass was resuspended with sterile distilled water and encapsulated with the encapsulation materials for skimmed milk and Arabic gum with a ratio of $3: 7(\mathrm{w} / \mathrm{w})$ of biomass and encapsulation materials. Then, the mixture was homogenized with the vortex. This result could be evenly mixed and ready to dry with BUCHI mini spray drying at an inlet temperature of $100^{\circ} \mathrm{C}$ and an outlet temperature of $65^{\circ} \mathrm{C}$. Probiotic powder from L. plantarum $\mathrm{DJ} 2$ and L. plantarum $\mathrm{DJ} 3$ were obtained and used for further analysis (Nunes et al., 2018).

\section{Resistance of Probiotics During Spray Drying Process}

Total LAB during spray drying is needed to calculate the effect of the drying process and encapsulation materials on culture preservation. Changes in the viability of LAB probiotics before and after the drying process using spray drying were determined by the total plate count. Mixture $0.1 \mathrm{ml}$ of bacterial cells and each encapsulated material: Arabic gum and skimmed milk was taken using pippet and put in $9.9 \mathrm{ml}$ of $0.85 \% \mathrm{NaCl}$ solution $\left(10^{-1}\right)$, the dilution was continued until $10^{-9}$ and poured into $1 \mathrm{ml}$ in a petri dish then added MRS agar media and incubated at room 
temperature for $48 \mathrm{~h}$. The same method was done after the spray drying process by weighing $0.1 \mathrm{~g}$ of probiotic powder. Probiotic powder means probiotic lactic acid bacteria which are already in flour/powder form after spray drying process. Total lactic acid bacteria before spray drying was compared with after spray drying (Zhang Zhu et al., 2016).

\section{Changes in Viability of LAB Probiotics from Spray Drying During Storage}

Weighed $0.1 \mathrm{~g}$ of probiotic powder was taken and put into a test tube containing $9.9 \mathrm{ml}$ of $0.85 \% \quad \mathrm{NaCl}$ solution ( $10^{-1}$ dilution), then continued to $10^{-9}$ and poured into $1 \mathrm{ml}$ in a petri dish and MRS agar was added, Incubated for $48 \mathrm{~h}$ at room temperature. The viability of lactic acid bacteria (LAB) was observed every week for one month of storage at $4^{\circ} \mathrm{C}$ (modified from Gul and Atalar 2019).

\section{Total Mold and Yeast}

Weighed $0.1 \mathrm{~g}$ of probiotic powder and diluted to $10^{-1}$ until $10^{-2}(\mathrm{NaCl} 0,85 \%)$. $1 \mathrm{ml}$ of the dilution was transferred to a petri dish, then PDA was poured into a petridish that already has an inoculum. Then incubated at room temperature for $5 \mathrm{~d}$ (Modified from Chay et al., 2017).

\section{Data Analysis}

The Analysis of t-test was used to perform data analysis and continued with Least Significance Difference (LSD) test for comparison of mean of treatments if had a significant effect $(\mathrm{P}<0.05)$ or highly significant effect $(\mathrm{P}<0.01)$.

\section{RESULTS AND DISCUSSION}

\section{Resistance of Probiotics During Spray Drying Process}

Different encapsulation materials were significant different $(\mathrm{P} \leq 0.05)$ on number of bacterial cell. The results showed that after drying the viability of L.plantarum DJ2 and L.plantarum DJ3 decreased (Table 1). The viability of L.plantarum DJ2 with skimmed milk before treatment was $10.85 \pm 0.06 \log \mathrm{CFU} / \mathrm{g}$ and decreased after spray drying to $10.28 \pm 0.01 \log \mathrm{CFU} / \mathrm{g}$, encapsulated with arabic gum decreased from $10.64 \pm 0.02 \log \mathrm{CFU} / \mathrm{g}$ to $10.04 \pm 0.01 \log \mathrm{CFU} / \mathrm{g}$ after drying. Meanwhile, L.plantarum DJ3 showed that the result of skimmed milk before drying was $9.84 \pm 0.00 \log \mathrm{CFU} / \mathrm{g}$ and decreased after spray drying to $9.73 \pm 0.06 \log \mathrm{CFU} / \mathrm{g}$, encapsulated with arabic gum has decreased from $10.53 \pm 0.01 \quad \log \mathrm{CFU} / \mathrm{g}$ to $9.32 \pm 0.00 \log \mathrm{CFU} / \mathrm{g}$.

The results of this study showed that encapsulated with skimmed milk and drying, the LAB viability of $L$. plantarum DJ2 and L. plantarum DJ3 decreased which was greater than using arabic gum. The decrease in the number of L.plantarum DJ2 using skimmed milk was 5.1 log cycles, with Arabic gum $3.3 \log$ cycles. Meanwhile, the decrease in the number of L.plantarum DJ3 using skimmed milk was $1.5 \log$ cycles, with arabic gum $1.3 \log$ cycles. According to Vázquez-Maldonado et al. (2020) in spray drying which caused the damage due to processing or environmental conditions. Environmental conditions include $\mathrm{pH}$, atmospheric oxygen, humidity, exposure to high temperatures and light irradiation.

Dry products from spray drying process have a number of living microorganisms. Dry products are a suitable form for storage purposes and applications in the development of probiotic food products cycles. From this study stated that the use of Arabic gum is as good as an encapsulation material. The use of Arabic gum is as good as an encapsulation material based on resistance of probiotics during spray drying process. Cahya et al. (2018) stated that Arabic gum is recommended for the encapsulation of the spray drying process because Arabic gum contains glycoprotein and arabinogalactan protein group as a thickener and emulsifier. The use of Arabic gum as a thickener, flavor, and emulsion film. Arabic gum has low viscosity and high solubility. The advantages of Arabic gum are due to its viscosity, 
solubility, microencapsulation capacity and association with water and oil. One of the reasons Arabic gum is good for encapsulation is its low viscosity emulsion properties and solubility (Mariod, 2018).

The types of LAB used in this study were L.plantarum DJ2 and L.plantarum DJ3 and showed different results of decreasing viability in various materials. The total amount of LAB that survived in the spray drying process depends on the type of bacteria. When related with research conducted by Perdana et al. (2015), spray drying can reduce the viability of $L$. plantarum WCFS1 during drying where the factors affecting the decrease in LAB viability are temperature and air content for the first $0.5 \mathrm{~s}$ after the atomization process. According to Papadimitriou et al. (2016) LAB could experience heat stress including during the fermentation process of food at temperatures $\left(>60^{\circ} \mathrm{C}\right)$ due to high temperatures are a set of heat induced proteins known as heat shock proteins. The heating treatment of L.plantarum DJ2 and L.plantarum DJ3 can cause damage to several protein in cells that reduce cell ability.

Table 1. Resistance of probiotics during spray drying process

\begin{tabular}{|c|c|c|}
\hline \multirow[t]{2}{*}{ Encapsulation Materials } & \multicolumn{2}{|c|}{ Number of living cells $(\log \mathrm{CFU} / \mathrm{g}$ ) } \\
\hline & L.plantarum DJ2 & L.plantarum DJ3 \\
\hline \multicolumn{3}{|l|}{ Skim milk } \\
\hline Before drying & $10.85 \pm 0.06^{\mathrm{b}}$ & $9.84 \pm 0.00^{\mathrm{a}}$ \\
\hline After drying & $10.28 \pm 0.01^{\mathrm{a}}$ & $9.73 \pm 0.00^{\mathrm{a}}$ \\
\hline \multicolumn{3}{|l|}{ Arabic gum } \\
\hline Before drying & $10.64 \pm 0.02^{b}$ & $10.53 \pm 0.01^{b}$ \\
\hline After drying & $10.04 \pm 0.01^{\mathrm{a}}$ & $9.32 \pm 0.00^{\mathrm{a}}$ \\
\hline
\end{tabular}

Remarks : * Mean values within a column followed by the different letters are significantly different at $\mathrm{p}<0.05$ according to least significance difference (LSD) test

\section{Changes in The Viability of LAB of Dry Probiotic Products during Storage}

Data on the viability of dry probiotics of L.plantarum DJ2 and L.plantarum DJ3 during one month of storage are presented in Table 2. The use of 3:7 (w/w) biomass and material ratio for L.plantarum DJ2 decreased in the viability of LAB after one month of storage, from $9.82 \pm 0.02 \mathrm{log}$ $\mathrm{CFU} / \mathrm{g}$ to $9.38 \pm 0.04 \mathrm{log} \mathrm{CFU} / \mathrm{g}$ for skimmed milk, whereas with arabic gum from $9.53 \pm 0.01 \log \mathrm{CFU} / \mathrm{g}$ to $8.81 \pm 0.04$ $\log \mathrm{CFU} / \mathrm{g}$, whereas for L.plantarum DJ3 using skimmed milk was $9.89 \pm 0.03 \mathrm{log}$ $\mathrm{CFU} / \mathrm{g}$ to $7.85 \pm 0.02 \log \mathrm{CFU} / \mathrm{g}$, with arabic gum was $9.48 \pm 0.02 \mathrm{log} \mathrm{CFU} / \mathrm{g}$ to $7.61 \pm 0.02 \log \mathrm{CFU} / \mathrm{g}$ after one month of storage.

Storage is carried out to see the ability of probiotics to survive because this product is expected to be stored at cold temperatures $\left(4^{\circ} \mathrm{C}\right)$ for a certain period of time. The storage of probiotic products actually caused decrease in the viability of LAB every week for one month of storage at $4^{\circ} \mathrm{C}$. Storage conditions such as time and temperature may affect microorganism freezing and cooling conditions for no more than 3 months showed the best conditions for bacteria. High temperatures can reduce the viability of microorganisms, because high temperatures increase the microbial load (Cabello-Olmo et al., 2020).

The results of changes in the viability of LAB probiotics resulting from spray drying during storage for up to 4 weeks showed that the use of skimmed milk was better to be able to maintain the viability of probiotic powder both on L.plantarum DJ2 and L.plantarum DJ3. Maciel et al. (2014) stated that the two encapsulation ingredients, namely sweet whey and skimmed milk, have probiotic counts above $10^{6} \mathrm{CFU} / \mathrm{g}$ at both storage temperatures $\left(4^{\circ} \mathrm{C}\right.$ and $\left.25^{\circ} \mathrm{C}\right)$ after $90 \mathrm{~d}$ of storage, however skimmed milk has the advantage 
that it allows for increased probiotic viability.

Other literature stated that the reason skimmed milk is used as microencapsulation is that it has carbohydrate-based wall materials and amphililic properties which have the functional and physicochemical properties required for core microencapsulation materials (Gul and Atalar, 2019).

Table 2. Viability of dry probiotic products after storage

\begin{tabular}{|c|c|c|}
\hline \multirow{2}{*}{ Storage Time } & \multicolumn{2}{|c|}{ Number of living cells (log CFU/g) } \\
\hline & L.plantarum DJ2 & L.plantarum DJ3 \\
\hline \multicolumn{3}{|l|}{ 1st week storage } \\
\hline Skim milk & $9.82^{\mathrm{a}} \pm 0.02$ & $9.89^{a} \pm 0.03$ \\
\hline Arabic gum & $9.53^{\mathrm{a}} \pm 0.01$ & $9.48^{\mathrm{a}} \pm 0.02$ \\
\hline \multicolumn{3}{|l|}{ 2nd week storage } \\
\hline Skim milk & $9.50^{\mathrm{b}} \pm 0.01$ & $9.38^{\mathrm{b}} \pm 0.01$ \\
\hline Arabic gum & $9.04^{\mathrm{b}} \pm 0.02$ & $9.32^{\mathrm{b}} \pm 0.01$ \\
\hline \multicolumn{3}{|l|}{ 3rd week storage } \\
\hline Skim milk & $9.43^{\mathrm{b}} \pm 0.03$ & $9.23^{\mathrm{c}} \pm 0.02$ \\
\hline Arabic gum & $8.95^{\mathrm{b}} \pm 0.04$ & $7.70^{\mathrm{b}} \pm 0.02$ \\
\hline \multicolumn{3}{|l|}{ 4rd week storage } \\
\hline Skim milk & $9.38^{b} \pm 0.04$ & $7.85^{\mathrm{d}} \pm 0.01$ \\
\hline Arabic gum & $8.81^{\mathrm{c}} \pm 0.04$ & $7.61^{c} \pm 0.02$ \\
\hline
\end{tabular}

Remarks : * Mean values within a column followed by the different letters are significantly different at $\mathrm{p}<0.05$ according to least significance difference (LSD) test

\section{Total Mold and Yeast of Dry Probiotic Products}

The results of this study showed that different encapsulation materials had significant different $(\mathrm{P} \leq 0.05)$ on mold and yeast contamination of probiotic powder after storage for one month was presented in Table 3. Total mold and yeast in probiotic powder of $L$. plantarum DJ2 with skimmed milk was $1.40 \pm 0.01 \log \mathrm{CFU} / \mathrm{g}$ and arabic was $2.72 \pm 0.02 \log \mathrm{CFU} / \mathrm{g}$, whereas probiotic powder of L.plantarum DJ3 with skimmed milk was $1.26 \pm 0.02 \log \mathrm{CFU} / \mathrm{g}$ and with arabic gum was $4.20 \pm 0.01 \log \mathrm{CFU} / \mathrm{g}$.

In microbiological research and microbial production, contamination became a major problem. The contaminants included molds that could grow on culture media (Xiao-Xiao Shi et al., 2019).

Table 3. Total fungi and yeast in probiotic products

\begin{tabular}{ccc}
\hline Encapsulation Materials & \multicolumn{2}{c}{ Total Fungi and Yeast in Probiotic Products (log CFU/g) } \\
\cline { 2 - 3 } & L.plantarum DJ2 & L.plantarum DJ3 \\
Skim milk & $1.40 \pm 0.01$ & $1.26 \pm 0.02$ \\
Arabic gum & $2.72 \pm 0.02$ & $4.20 \pm 0.01$ \\
\hline
\end{tabular}

Mould and yeast can be present in some media due to improper heat treatment, poor sanitation during processing and on the material used, and secondary contamination ( $\operatorname{Rad}$ et al., 2019). Probiotic powder is a good medium for the growth of pathogenic microbes. In an industry, the biggest problem of concern is food spoilage, one of which is caused by microbes which caused economic losses for producers and consumers, if not handled properly it will have a negative effect on the company's brand. Companies need to take various ways to avoid spoilage and increase the shelf life of products by means of chemical fungicides and preservative (Salas et al., 2017). 


\section{CONCLUSION}

In conclusion, both Arabic gum and skimmed milk can be used as encapsulant where storage of dry probiotic products is recommended during 4 weeks. The suggestion for further research is to observe the types of molds and yeasts present after 4 weeks of storage

\section{CONFLICT OF INTEREST}

We certify that there is no conflict of interest with any financial, personal, or other relationships with other people or organization related to the material discussed in the manuscript.

\section{REFERENCES}

Afzaal, M., Khan, A. U., Saeed, F., Ahmed, A., Ahmad, M. H., Maan, A. A., Tufail, T., Anjum, F. M., \& Hussain, S. (2019). Functional exploration of free and encapsulated probiotic bacteria in yogurt and simulated gastrointestinal conditions. Food Science \& Nutrition, 7(12), 3931-3940. https://doi.org/10. $1002 /$ fsn3.1254

BPS-Statistics Indonesia. (2020). Consumption of calorie and protein of Indonesia and province. In BadanPusat Statistics (Issue September).

Cabello-Olmo, M., Oneca, M., Torre, P., Díaz, J., Encio, I., Barajas, M., \& Araña, M. (2020). Influence of storage temperature and packaging on bacteria and yeast viability in a plant-based fermented food. Foods, 9(302), 1-16. https://doi.org/10.3390/foods9030302

Cahya, A. P., Syaflan, M., \& Ngatirah, N. (2018). Probiotic (Lactobacillus casei) encapsulation using the method of spray drying with combined prebiotic from iles-iles (Amorphopallus oncophyllus) and protectant agent (Skim Milk, Gum Arabic, Maltodextrin). Indonesian Food and Nutrition Progress, 15(2), 61. https://doi.org/10.22146/ifnp.33423

Chavarri, M., Maranon, I., \& Carmen, M. (2012). Encapsulation technology to protect probiotic bacteria. In Probiotics. InTech. https://doi.org/ 10.5772/50046

Chay, C., Dizon, E. I., Elegado, F. B., Norng, C., Hurtada, W. A., \& Raymundo, L. C. (2017). Isolation and identification of molds and yeasts in medombae, a rice wine starter culture from Kompong Cham Province, Cambodia. Food Research, 1(6), 213220. https://doi.org/10.26656/fr.2017 .6 .101

Czyżak-Runowska, G., Wójtowski, J. A., Gogół, D., Wojtczak, J., Skrzypczak, E., \& Stanisławski, D. (2020). Properties of rennet cheese made from whole and skimmed summer and winter milk on a traditional polish dairy farm. Animals, 10(10), 1-12. https://doi.org/10.3390/ani10101794

Diaz Carrasco, J. M., Casanova, N. A., \& Fernández Miyakawa, M. E. (2019). Microbiota, gut health and chicken productivity: what is the connection?. Microorganisms, 7(10), 1-15. https://doi.org/10.3390/microorganis ms7100374

Ekue Nathalia Bonjah, B. T. F., \& Ndjouenkeu, R. (2017). Production of probiotic biomass (Lactobacillus rhamnosus IS9) against salmonella sp for use as a feed supplement in poultry. International Journal of Current Microbiology and Applied Sciences, 6(6), 3286-3298. https://doi. org/10.20546/ijcmas.2017.606.386

Gul, O., \& Atalar, I. (2019). Different stress tolerance of spray and freeze dried Lactobacillus casei Shirota microcapsules with different encapsulating agents. Food Science and Biotechnology, 28(3), 807816. https://doi.org/10.1007/s10068-0180507-x

Kavitake, D., Kandasamy, S., Devi, P. B., \& Shetty, P. H. (2018). Recent developments on encapsulation of lactic acid bacteria as potential starter 
culture in fermented foods - A review. Food Bioscience, 21, 34-44. https:// doi.org/10.1016/j.fbio.2017.11.003

Khanvilkar, A. M., Ranveer, R. C., \& Sahoo, A. K. (2016). Carrier materials for encapsulation of bio-active components of food. International Journal of Pharmaceutical Sciences Review and Research, 40(1), 62-73.

Leyva Salas, M., Mounier, J., Valence, F., Coton, M., Thierry, A., \& Coton, E. (2017). Antifungal microbial agents for food biopreservation - a review. Microorganisms, 5(3), 1-37. https:// doi.org/10.3390/microorganisms5030 037

Maciel, G. M., Chaves, K. S., Grosso, C. R. F., \& Gigante, M. L. (2014). Microencapsulation of Lactobacillus acidophilus La-5 by spray-drying using sweet whey and skim milk as encapsulating materials. Journal of Dairy Science, 97(4), 1991-1998. https://doi.org/10.3168/jds.2013-7463

Mariod, A. A. (2018). Gum Arabic 24 Functional properties of gum Arabic. Academic Press, Massachusetts.

Markowiak, P., \& Śliżewska, K. (2018). The role of probiotics, prebiotics and synbiotics in animal nutrition. Gut Pathogens, 10(1), 21. https://doi.org/ 10.1186/s13099-018-0250-0

Musa, H. H., Ahmed, A. A., \& Musa, T. H. (2019). Chemistry, biological, and pharmacological properties of gum arabic. In Reference Series in Phytochemistry (pp. 797-814). https://doi.org/10.1007/978-3-31978030-6_11

Nunes, G. L., Motta, M. H., Cichoski, A. J., Wagner, R., Muller, É. I., Codevilla, C. F., Silva, C. de B. da, \& Menezes, C. R. de. (2018). Encapsulation of Lactobacillus acidophilus La-5 and Bifidobacterium Bb-12 by spray drying and evaluation of its resistance in simulated gastrointestinal conditions, thermal treatments and storage conditions. Ciência Rural, 48(6). https://doi.org/10.1590/0103-

\section{$8478 \mathrm{cr} 20180035$}

Oberoi, K. (2019). Microencapsulation: an overview for the survival of probiotic bacteria. Journal of Microbiology, Biotechnology and Food Sciences, 9(2), 280-287. https://doi.org/10.15 414/jmbfs.2019.9.2.280-287

Ozdal, T., Yolci-Omeroglu, P., \& Tamer, E. C. (2020). Biotechnological Progress and Beverage Consumption - role of encapsulation in functional beverages. Academic Press, Massachusetts.

Papadimitriou, K., Alegría, Á., Bron, P. A., de Angelis, M., Gobbetti, M., Kleerebezem, M., Lemos, J. A., Linares, D. M., Ross, P., Stanton, C., Turroni, F., van Sinderen, D., Varmanen, P., Ventura, M., Zúñiga, M., Tsakalidou, E., \& Kok, J. (2016). Stress physiology of lactic acid bacteria. microbiology and molecular biology reviews, 80(3), 837-890. https://doi. org/ 10.1128/MMBR.00076-15

Perdana, J., Aguirre Zubia, A., Kutahya, O., Schutyser, M., \& Fox, M. (2015). Spray drying of lactobacillus plantarum WCFS1 guided by predictive modeling. Drying Technology, 33(15-16), 1789-1797. https://doi.org/10.1080/07373937.201 5.1026975

Rad, A. H., Javadi, M., Kafil, H. S., Pirouzian, H. R., \& Khaleghi, M. (2019). The safety perspective of probiotic and non-probiotic yoghurts: a review. Food Quality and Safety, 3(1), 9-14. https://doi.org/10.1093/ fqsafe/fyz006

Rodrigues, F. J., Cedran, M. F., Bicas, J. L., \& Sato, H. H. (2020). Encapsulated probiotic cells: Relevant techniques, natural sources as encapsulating materials and food applications - A narrative review. Food Research International, 137, 109682. https://doi .org/10.1016/j.foodres.2020.109682

Samedi, L., \& Charles, A. L. (2019). Viability of 4 probiotic bacteria microencapsulated with arrowroot 
starch in the simulated gastrointestinal tract (GIT) and yoghurt. Foods, 8(5), 175. https://doi.org/10.3390/foods 80 50175

Shi, X.-X., Qiu, H.-P., Wang, J., Zhang, Z., Wang, Y.-L., \& Sun, G.-C. (2020). Correction: A handy method to remove bacterial contamination from fungal cultures. PLOS ONE, 15(1), e0228293. https://doi.org/10.1371/ journal.pone.0228293

Sosnik, A., \& Seremeta, K. P. (2015). Advantages and challenges of the spray-drying technology for the production of pure drug particles and drug-loaded polymeric carriers. Advances in Colloid and Interface Science, 223, 40-54. https://doi.org/ 10.1016/j.cis.2015.05.003

Vázquez-Maldonado, D., Espinosa-Solis, V., Leyva-Porras, C., AguirreBañuelos, P., Martinez-Gutierrez, F., Román-Aguirre, M., \& SaavedraLeos, M. Z. (2020). Preparation of spray-dried functional food: effect of adding bacillus clausii bacteria as a co-microencapsulating agent on the conservation of resveratrol. Processes, 8(7), 1-13. https://doi.org/ $10.3390 / \mathrm{pr} 8070849$

Yirga, H. (2015). The use of probiotics in animal nutrition. Journal of Probiotics \& Health, 03(02), 1-10. https:// doi.org/10.4172/2329-8901.1000132

Zhou, W., Wang, Y., Lin, J., Founou, L. L., Founou, R. C., Essack, S. Y., CasalsPascual, C., Vergara, A., Vila, J., Bahrndorff, S., Alemu, T., Alemneh, T., Lund Nielsen, J., Ezenwa, V. O., Gerardo, N. M., Inouye, D. W., Medina, M., Xavier, J. B., Subirats, J., Angelakis, E. (2016). Crossm phylogenetically related and correlated with the cow' $\mathrm{s}$ capacity to harvest. PLoS ONE, 7(1), 108-119.

Zhu, Z., Luan, C., Zhang, H., Zhang, L., \& Hao, Y. (2016). Effects of spray drying on Lactobacillus plantarum BM-1 viability, resistance to simulated gastrointestinal digestion, and storage stability. Drying Technology, 34(2), 177-184. https://doi.org/10.1080/07373937.201 5.1021009 